\title{
Emerging Roles of IL-33/ST2 Axis in Renal Diseases
}

\author{
Wei-Yu Chen ${ }^{1}$, Lung-Chih $\mathrm{Li}^{1,2}$ and Jenq-Lin Yang ${ }^{1, *}$ \\ 1 Institute for Translational Research in Biomedicine, Kaohsiung Chang Gung Memorial Hospital, \\ Kaohsiung 833, Taiwan; wychen624@cgmh.org.tw (W.-Y.C.); r5239@cgmh.org.tw (L.-C.L.) \\ 2 Division of Nephrology, Department of Internal Medicine, Kaohsiung Chang Gung Memorial Hospital and \\ Chang Gung University College of Medicine, Kaohsiung 833, Taiwan \\ * Correspondence: jyang@adm.cgmh.org.tw; Tel.: +886-7-7317123 (ext. 8593); Fax: +886-7-7317123 (ext. 8569)
}

Academic Editor: Alan Parrish

Received: 17 March 2017; Accepted: 5 April 2017; Published: 7 April 2017

\begin{abstract}
Renal diseases, including acute kidney injury (AKI) and chronic kidney disease (CKD), have a great impact on health care systems worldwide. Similar to cardiovascular diseases, renal diseases are inflammatory diseases involving a variety of cytokines. Primary causes of renal injury include ischemia, uremic toxins, bacteremia, or nephrotoxicity. Inflammation represents an important component following kidney injury. Interleukin (IL)-33 is a member of the IL-1 cytokine family, which is widely expressed in epithelial barrier tissues and endothelial cells, and mediates both tissue inflammation and repair responses. IL-33 is released as a nuclear alarmin in response to tissue damage and triggers innate and adaptive immune responses by binding to its receptor, suppression of tumorigenicity 2 (ST2). Recent evidence from clinical and experimental animal studies indicates that the IL-33/ST2 axis is involved in the pathogenesis of CKD, renal graft injury, systemic lupus nephritis, and AKI. In this review, we discuss the pathological and tissue reparative roles of the IL-33/ST2 pathway in different types of renal diseases.
\end{abstract}

Keywords: interleukin-33; chronic renal disease; acute renal injury; inflammation

\section{Introduction}

Renal diseases, including acute kidney injury (AKI) and chronic kidney disease (CKD), are a public health priority and cause a major burden to health care systems worldwide [1,2]. AKI, characterized by sudden loss of kidney function, is a common complication of hospitalization and associates with short-term morbidity and high mortality rates greater than $50 \%$ in consequence of commonly association with severe complication [3,4]. Renal interstitial fibrosis and parenchymal tubular cell loss are common outcomes of chronic renal disorders during disease progression [5,6].

Of note, cardiovascular diseases (CVDs) are the leading cause of mortality in patients with renal diseases [7]. CVDs and CKDs share certain risk factors and pathophysiology [8]. Both traditional (diabetes, hypertension and hyperlipidemia) and non-traditional (endothelial dysfunction, oxidative stress and inflammation) risk factors contribute to the initiation and progression of atherosclerotic CVD and CKD. Among these factors, inflammation is an important player involving a variety of chemokines and cytokines.

Cytokines are involved in the progression of renal fibrosis and tissue damage [9]. Pro-inflammatory cytokines (e.g., TNF- $\alpha$, IFN- $\gamma$, IL-1 $\beta$, IL-6, IL-17, and IL-23) and anti-inflammatory cytokines (e.g., IL-4, TGF- $\beta$, and IL-10) expressed by resident and infiltrated immune cells are important mediators for the injury and repair responses [10]. Inflammation [10,11], oxidative stress [12], drug toxicity [13], infection [14], and diabetes [15] are primary factors involved in the pathogenesis of renal injury. In this review, we discuss the pathological and protective roles of the IL-33/ST2 axis involved in CKD and AKI. 


\subsection{Interleukin-33 and ST2 Signaling}

IL-33 was first reported to act as a nuclear factor in high endothelial venules in 2003 [16]. In 2005, Schmitz et al. identified IL-33 as a member of the IL-1 family and a ligand for the orphan receptor, suppression of tumorigenicity 2 (ST2, also known as IL1RL1) [17]. IL-33 functions as a tissue-derived nuclear alarmin $[17,18]$, and is constitutively expressed at high levels in epithelial barrier tissues and endothelial barriers $[18,19]$. The receptor complex for IL-33 consists of the specific subunit of ST2, encoded by the IL1RL1 gene, and the coreceptor, IL-1 receptor accessory protein (IL-1RAcP) [18,20]. Two major transcription variants of ST2, the full-length transmembrane form (ST2L) and the soluble form (sST2), have been identified [21]. The sST2 lacks the transmembrane domain and binds to IL-33 as a decoy receptor and has anti-inflammatory properties by regulating IL-33 activity [22,23]. Stimulation of the IL-33 receptor, ST2L, elicits recruitment of MyD88, IRAK1, IRAK4, and TRAF6, then activates downstream NF- $\mathrm{kB}$, c-Jun N-terminal kinases (JNK), p38, and extracellular signal-regulated kinase (ERK) signaling pathways (Figure 1A).
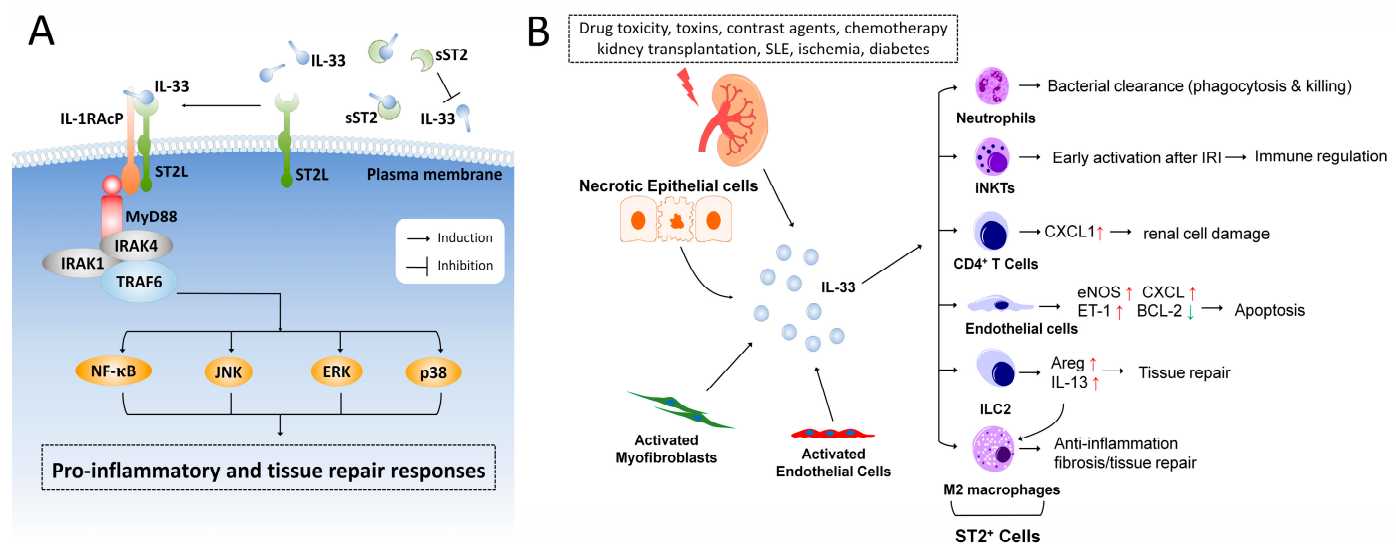

Figure 1. IL-33/ST2 signaling in renal injury. (A) IL-33 binds to the receptor complex comprised of ST2L and IL-1RAcP on the cell membrane and induces recruitment of MyD88, IRAK1, IRAK4 and TRAF6, thereby activating the downstream NF- $\mathrm{KB}, \mathrm{JNK}$, p38, and ERK pathways. The extracellular soluble form of ST2 (sST2) binds IL-33 as a decoy receptor and has been postulated to be a biomarker in various inflammatory diseases; (B) Exogenous factors (such as drug toxicity, toxins, contrast agents, and chemotherapy), kidney transplantation, and diseases associated with nephropathies (SLE, renal ischemia, and diabetes) lead to upregulation of IL-33 in the renal tissues. Upon injury, necrotic epithelial cells, activated myofibroblasts, or endothelial cells release IL-33, triggering an inflammatory response and tissue repair processes by targeting the ST2-expressing cells.

IL-33 was detected in endothelial cells of blood vessels in healthy human tissues [24], but not in mouse tissues [19]. However, IL-33 was upregulated in endothelial cells of inflamed mouse tissues [19,25-27]. Apoptotic cells inactivated endogenous IL-33 by caspases to avoid triggering unnecessary immune responses [28,29]. Endogenous IL-33 was constitutively expressed in cell nuclei and was able to associate with chromatin by binding histone $\mathrm{H} 2 \mathrm{~A} / \mathrm{H} 2 \mathrm{~B}$, although its nuclear role still remains unclear [30]. In human endothelial cells, IL-33 likely acts as an extracellular cytokine but not as a nuclear factor in regulating gene expression [31]. Interestingly, nuclear IL-33 was shown to interact with NF- $\mathrm{KB}$ and dampen NF- $\mathrm{kB}$-stimulated gene transcription [32]. The nuclear function and stability of IL-33 were regulated by the enzyme ubiquitin-specific protease 17 (USP17) through deubiquitination of IL-33 both at the K48 and K63 sites [33].

Full length IL-33 is released into the extracellular matrix during tissue damage, cell necrosis, or mechanical stress, following exposure to allergens or infection with viruses or parasites [34-36]. The full length form of extracellular IL-33 was bioactive; in addition, it can be processed via proteases (cathepsin $\mathrm{G}$ and elastase) to become shorter hyperactive forms [23,37]. A recent study reported that 
IL-33 is susceptible to cysteine oxidation [38]. The biological activity of IL-33 was rapidly inactivated in the extracellular environment by forming two disulfide bonds, resulting in a conformational change and disruption of the ST2 binding site [38]. The release of IL-33 from the nucleus to the extracellular matrix was mediated by a nuclear pore complex in an ATP-dependent manner [21]. Detailed molecular mechanisms involved in regulating IL-33 translocation in living cells remains poorly understood.

The targeted deletion of the nucleus localization domain (amino acid 1-68) of IL-33 led to the spontaneous secretion of the IL-33 protein and triggered a lethal inflammatory response in the IL-33 tm1 knock-in mouse model through ST2-dependent signaling [39]. This suggests that physiological control of IL-33 release is crucial and tightly regulated during tissue homeostasis.

After being released, IL-33 activates various types of immune cells, including neutrophils, eosinophils, mast cells, type 2 helper T cells (Th2), and group 2 innate lymphoid cells (ILC2s), which secrete large amounts of IL-5 and IL-13 for regulation of innate and adaptive immune responses [36,40,41]. IL-33 thus serves as a nuclear alarmin to sense damage and alert adjacent cells and tissues following infection or tissue injury, and therefore has the potential to influence a broad range of diseases [24].

\subsection{Distribution of IL-33 and ST2 in the Kidney}

The distribution and regulation of IL-33 in different tissues and specific cell types have been comprehensively reviewed [42-44]. IL-33 is widely expressed in various organs, including heart, brain, kidney, liver, spleen, and lung. At cellular level, IL-33 is predominantly expressed by non-immune cells, including epithelial cells, endothelial cells, and fibroblasts. Immune cells such as activated macrophages were also reported to be sources of IL-33 [45].

Only a few studies have comprehensively investigated the cellular expression of IL-33 and ST2 in kidney tissues following injury. In humans, IL-33 was constitutively expressed and transported to the endothelial nuclei of renal large and small vessels [24]. In mice, IL-33 mRNA is expressed in the kidney tissue [17]. Chen et al. have shown that the IL-33 protein is predominantly distributed in renal tubulointerstitial cells that co-express vimentin and $\alpha$-smooth muscle actin ( $\alpha$-SMA) by using immunofluorescent staining. The number of $\mathrm{IL}^{-33^{+}} \mathrm{Vimentin}^{+}$tubulointerstitial cells was markedly increased in the obstructed kidney after unilateral ureteral obstruction (UUO) surgery. $\mathrm{CD} 1^{+}$peritubular vascular endothelial cells were relatively minor sources of IL-33 in the control and obstructed kidney [46]. No evident IL-33 expression in glomeruli and tubular epithelial cells was observed in either healthy or obstructed kidney of the UUO mouse model, which suggests that tubulointerstitial cells are major sources of IL-33 in the obstructed kidney [46]. Whether activated immune cells produce IL-33 in the kidney remains to be investigated.

In humans and mice, the transmembrane form ST2L and soluble form SST2 are widely expressed in various organs, including the heart, brain, spleen, lungs, skin, and kidneys [42-44]. Endothelial cells [47], cardiomyocytes [26], CD4 ${ }^{+} \mathrm{T}$ cells [27], macrophages [48], neutrophils, iNKT cells, and ILC2 cells $[49,50]$ were shown to respond to IL-33 activation through their membrane receptor ST2L. The expression of ST2L or IL-33-responsiveness in tubular epithelial cells (including proximal tubular cells, distal tubular cells, collecting duct cells, and pelvic urothelium), mesangial cells or podocytes has not been fully investigated or reported. The major sources of soluble ST2 (sST2) during tissue injury remain largely unknown. A recent study by Zhang et al. demonstrated that intestinal stromal cells and T cells are major sources of sST2 during in mouse model of graft-versus-host disease (GVHD), indicating that T cells are potential sources of circulating sST2 [51]. Endothelial cells and fibroblasts also secrete SST2 in response to activation [52]. In the context of myocardial injury, the sources of circulating serum ST2 are extra-myocardial [53], which indicates that peripheral or systemic inflammation likely attribute to the elevated production of circulation SST2.

Several lines of evidence both from clinical and animal studies demonstrate that the IL-33/ST2 axis is involved in renal diseases. The levels of IL-33 and soluble ST2 are generally tested to evaluate 
severity and prognosis of renal diseases clinically. Below, we focus on recent findings of the IL-33/ST2 axis involved in renal diseases in human and animal models.

\section{IL-33 in Chronic Kidney Injury}

\subsection{IL-33 and Chronic Kidney Disease (CKD)}

CKD is defined as the presence of renal abnormalities in either function or structure lasting more than three months [54]. Currently serum creatinine, urea nitrogen, and urine analysis are used as biomarkers to monitor renal function [55-57]. However, evidence has indicated that these biomarkers are not optimal for detecting early stage CKD. Hence, new potential biomarkers for early CKD have been explored. Bao et al. reported that SST2 serum levels were elevated and associated with disease severity and the level of parathyroid hormone positively correlates with SST2 concentration in non-dialysis CKD patients (stages 2-5) [58]. Patients were divided into three groups according to estimated glomerular filtration rate (group 1: CKD stage 2; group 2: CKD stages 3-4; group 3: CKD stage 5). IL-33 serum levels of CKD patients were not significantly changed in the three groups but serum levels of sST2 strongly correlated with severity of the disease [58]. Another report by Caner et al. demonstrated that IL-33 serum level was not better in early recognition of diabetic nephropathy [59]. The increase in IL-33 serum levels in diabetic nephropathy was not associated with kidney injury, whereas the increase might be a result of diabetes [59]. Musolino et al. reported that reduced IL-33 serum levels in multiple myeloma (MM) patients were associated with a more advanced stage of disease [60]. However, the IL-33 levels in MM patients with kidney failure were not statically significantly different in MM patients who did not have kidney failure [60]. Interestingly, Duan et al. reported that the serum IL-33 expression was predominantly increased in gout patients compared to healthy controls, and the IL-33 levels were higher in gout patients without kidney injury. Furthermore, IL-33 showed a negative correlation with biomarkers of kidney injury, such as creatinine and urea [61]. These findings together indicate that the serum levels of sST2 are more relevant to the progressive deterioration of kidney function. The above clinical studies indicate the serum level of IL-33 may not to be a proper biomarker for kidney failure or CKD.

\subsection{IL-33 and Diabetic Nephropathy}

Diabetic nephropathy (DN) is the most prevalent etiology for CKD with syndromes of progressive increases in excretion of urinary albumin (UAE), elevated blood pressure coupled with glomerular lesions and ultimately functional loss of glomerular filtration leading to renal failure [62]. Inflammatory responses are wildly triggered during DN progression, hence, inflammatory cytokines are profoundly involved in disease progression and severity; IL-33 has emerged as a candidate that is closely involved in the pathogenesis of DN [62]. A recent clinical study by Caner and colleagues investigated the association between IL-33 and DN by analyzing the serum levels of IL-33 from a healthy group, a diabetes mellitus (DM) group without any known renal diseases, and a DM group with microalbuminuria (MA) [59]. The results of Caner's study demonstrated that IL-33 levels in the DM and DM with MA groups were greater than the healthy group. No significant difference on serum levels of IL-33 was observed between the DM group and the DM with MA group [59]. Therefore, diabetes per se upregulates the serum level of IL-33, but it is not suitable to be used for early diagnosis of DN.

The expression of ST2L, the membrane-bound receptor of IL-33, is upregulated in human diabetic kidney tissues [63] and serum levels of sST2 is elevated in diabetic patients with critical limb ischemia and is directly associated with higher mortality at 1 year after revascularization [64]. The serum level of sST2 was also higher in patients with type 1 diabetes compared to the healthy counterparts [65]. A study by Miller et al. found that elevated serum levels of SST2 was correlated with diabetes but was not related to cardiovascular diseases and atherosclerosis in 639 human subjects [66]. The serum level of sST2, however, has no correlation to smoking, cholesterol, blood pressure, or atheroma (carotid 
intima media thickness, plaque presence). The results of Miller's study suggested that sST2 levels are related to diabetes markers in individuals largely without vascular disease [66]. Whether sST2 serum levels correlates with $\mathrm{DN}$ requires further investigations.

Patients with diabetic renal disease are more vulnerable to contrast-induced nephropathy [67]. Two animal studies revealed that both serum and renal tissue IL-33 levels are elevated in DM rats with contrast-induced nephropathy $[68,69]$. Melatonin therapy attenuated kidney IL-33 levels as well as ameliorating contrast-induced kidney injury, which suggests that kidney IL-33 levels may correlate with the degree of kidney injury in this model $[68,69]$.

Taken together, all lines of evidence demonstrate that IL-33 and SST2 are involved in diabetic complications. The role of IL-33 in DM and DM-associated kidney injury remains to be elucidated.

\subsection{IL-33 and Systemic Lupus Erythematosus (SLE) and Lupus Nephritis}

SLE is an autoimmune disease characterized by chronic inflammation involving multiple organ systems [70-72]. Lupus nephritis, a serious manifestation of SLE, contributes to the morbidity and mortality in these patients [70,73]. Cytokines and immune cells play a significant roles in the disease pathogenesis of SLE [71]. Deposits of immune complexes and autoantibodies initiate pro-inflammatory responses and leads to glomerular injury of the kidney [74].

Recent studies indicated that the IL-33/ST2 axis had a detrimental effect in the pathogenesis of SLE [75]. Moreover, IL-33 serum levels were increased in SLE patients compared with healthy individuals [76,77]. Another study by Mok et al. has shown that SST2 was significantly increased and positively correlated with SLE disease activity and severity. The sST2 level could be a potential biomarker for diagnosing SLE disease activity; however, the elevated serum sST2 level did not discriminate between active lupus nephritis and non-renal lupus [78]. Moreover, the serum IL-33 levels did not show a significant difference between the control group and SLE patients [78].

In an animal model of SLE, antibody-restrained IL-33 alleviates renal damages, suppresses expansion of Tregs and myeloid-derived Suppressor Cells (MDSC), and prohibits Th17 cells and pro-inflammatory responses, suggesting that blockage of IL-33 has a protective effect on SLE [76]. These results together suggest that IL-33 may be involved in the pathogenesis of SLE. Further investigations on the direct impact of the IL-33/ST2 pathway in lupus nephritis are required.

\subsection{IL-33 in Renal Cell Carcinoma}

Wang and colleagues analyzed the correlation of prognostic significance and tissue IL-33 expression in patients with clear-cell renal cell carcinoma (ccRCC) after surgical resection and found that IL-33 expression was significantly associated with advanced tumor stage [79]. Moreover, IL-33 was suggested as an independent prognostic factor of overall survival for patients with ccRCC after surgery [79].

\section{IL-33 in Acute Kidney Injury}

\subsection{IL-33 and Acute Kidney Injury (AKI)}

AKI is a common complication among hospitalized patients. This disorder, characterized by abrupt deterioration in kidney function and disruption of electrolyte and fluid homeostasis over hours to days, is associated with increased long-term risks of poor outcomes, including CKD, CVD and mortality [1]. An earlier study by Akcay et al. demonstrated that both serum and kidney IL-33 protein levels were upregulated in cisplatin-induced AKI; furthermore, neutralization of IL-33 by administration of sST2 protein reduced infiltrating $\mathrm{CD}^{+} \mathrm{T}$ cells and alleviated renal tubular damage [27]. This study indicated that IL-33 promotes AKI through the CD4 $4^{+} \mathrm{T}$ cells/CXCL1 axis.

In the ovalbumin-induced AKI mouse model, anti-IL-33 therapy reduced expression of kidney injury molecule-1, COX-2, iNOS, eNOS, and phosphorylated AMP-activated protein kinase (p-AMPK) in renal parenchyma [80]. Ferrostatin-1, an inhibitor of ferroptosis, was also shown to preserve 
renal function and prevented the upregulation of IL-33 in folic acid-induced AKI [81]. Kidney IL-33 expression was upregulated by paracetamol-induced nephrotoxicity [82]. Chrysin, a natural antioxidative and anti-inflammatory flavonoid, was shown to inhibit renal damage and decreases renal IL-33 expression in paracetamol-induced kidney injury [82]. These studies together indicate that IL-33 expression in the kidney is upregulated following acute renal injury in different models, and that tissue IL-33 expression possibly correlates with severity of renal damage. Thus, anti-IL-33 therapy is protective and might have beneficial effects in different AKI models [27,80].

\subsection{IL-33 and Obstructive Renal Injury}

Acute and chronic renal injuries lead to the formation of atubular glomeruli, proximal tubular cell loss, immune cells infiltration, collecting ducts remodeling, and interstitial fibrosis [83]. Fibrosis results in accumulation of extracellular matrix proteins with replacement of normal tissue with scar tissue and the fibrotic response is broadly considered irreversible in renal disease [5,6]. The mouse UUO model is widely studied to examine mechanisms of tubulointerstitial fibrosis via surgically induced obstructive renal injury [84]. Our previous study demonstrated that IL-33 is upregulated in the obstructed kidney after UUO [46]. Deficiency of IL33 reduced renal fibrosis and loss of tubular cells compared with wild type mice [46]. The $\alpha-\mathrm{SMA}^{+}$and vimentin ${ }^{+}$interstitial myofibroblasts were found to be major sources of IL-33 in the obstructive kidney [46]. Nuclear IL-33 likely functions as a molecular sensor for mechanical stress and the increased level of extracellular ATP, which consequently leads to the translocation of IL-33 to the extracellular matrix [21,85]. In the obstructed kidneys, the extracellular IL-33 possibly promotes renal tissue damage and inflammatory responses. These results suggest that the upregulation of IL-33/ST2 signaling in the obstructed kidney promotes tubular cell injury and interstitial fibrosis [46].

\subsection{IL-33-Mediated ILC2 Expansion in Acute Renal Injury}

In addition to the pro-inflammatory function, IL-33 induces pulmonary tissue repair responses by activating $\mathrm{ST}_{2}^{+}$immune cells, such as group 2 innate lymphoid cells (ILC2s) [86]. Recent studies have shown that ILC2 cells may have protective roles in renal injury as well. Riedel et al. identified the IL-33-responsive ILC2 population in human and mouse kidney [50]. In the model of adriamycin-induced glomerulosclerosis, sustained expansion of ST2 ${ }^{+}$ILC2 by exogenous IL-33 showed ameliorated renal injury. Moreover, eosinophils were required for IL-33-mediated renal protection [50]. Huang et al. demonstrated that IL-25-responsive ILC2 and type 2 multipotent progenitor (MPPtype2) cells promoted macrophage polarization toward the M2 phenotype in kidney and prevented acute renal ischemia/reperfusion injury [49]. Both studies suggest a protective role of ILC2 in renal protection against adriamycin or ischemia/reperfusion-induced kidney injury. The roles of IL-33 in tissue inflammation and repair by orchestrating immune responses in different models of renal injury will need further comprehensive investigation.

\subsection{IL-33 and Acute Renal Injury Associated with Infection}

Sepsis is a leading cause of mortality in the intensive care unit of hospitals worldwide [87]. An increasing body of evidence indicates that the IL-33/ST2 axis is involved in the initiation and progression of sepsis [88]. IL-33 and sST2 serum levels were elevated in sepsis patients [89-92]. Infection-induced renal dysfunction and AKI has also been described in moderate-to-severe scrub typhus [93]. The study by Shelite et al. reported that C57BL/6 mice with Orientia tsutsugamushi infection had a significant increase in IL-33 expression and ST2L in the kidney and liver. IL33-/mice showed markedly attenuated endothelial cell apoptosis. Exogenous IL-33 increased disease severity and lethality, which suggests a pathogenic function of IL-33 in Orientia infection-triggered EC damage [47].

Interestingly, administration of IL-33 was shown to be protective in mice infected with Candida albicans [94]. Tran et al. reported that IL-33 administration enhanced fungal clearance 
by increasing the phagocytosis activity of neutrophils. Moreover, deletion of IL13 abolished IL-33-mediated polarization of M2 macrophages and renal functional recovery [48]. This study indicates that therapeutic IL-33 may benefit patients with systemic candidiasis [42]. Taken together, elevation of the IL-33 protein alarms the host tissue and activates innate immune responses to promote bacterial clearance. The IL-33-mediated host responses and its role in infection-associated renal injury appear to be organism- and model-dependent.

\section{IL-33 in Renal Transplantation}

Renal ischemic injury (IRI) is one of the most important issues during kidney transplantation. Thierry and colleagues demonstrated that both serum and urine IL-33 levels were elevated after renal transplantation and determined that invariant natural killer T cells (iNKT) were potential targets of IL-33 in IRI [95]. Zhang et al. studied 64 renal transplant recipients and reported that serum IL-33 was significantly higher and correlated with the elevated production of Th2 cytokines and $\mathrm{CD} 4^{+} \mathrm{T}$ cells in chronic allograft dysfunction (CAD) patients compared to recipients with stable allograft function [96]. A study by Mansell et al. indicated that serum IL-33 level was positively associated with high cardiovascular risk for renal transplant patients. Mansell's study also found the elevated IL-33 level is associated with age, diabetes, serum phosphorus, microalbuminurea, and diminished GFR, which suggests that IL-33 increases the cardiovascular burden in renal transplant recipients [97].

The serum level of sST2 was found to be significantly increased after kidney transplantation [98], whereas sST2 was unable to induce podocyte injury in vitro or trigger proteinuria in rats, indicating that sST2 was a biomarker of recurrence but not the cause of corticosteroid-resistant idiopathic nephrotic syndrome (INS) [98].

In patients with graft-versus-host disease (GVHD), sST2 was shown to be a biomarker for the development of GVHD as well as correlating with mortality [99]. An elevated IL-33 level was found in nonhematopoietic cells in the gastrointestinal (GI) tract of patients during GVHD [100]. Mice with ST2 deficiency or dosed with sST2-Fc showed a markedly reduced GVHD lethality [100]. Recently, Zhang et al. demonstrated that intestinal stromal cells and T cells are major sources of sST2 during GVHD. ST2 blockage by a monoclonal antibody reduces sST2-producing T cells while maintaining protective ST2L-expressing T cells during GVHD [51]. The Zhang study provided evidence that blocking IL-33/ST2 signaling is a potential therapeutic target for severe GVHD. Moreover, the study by Matta et al. demonstrated the protective effect of allogeneic hematopoictic cell transplantation (peri-alloHCT) administration of IL-33 and the IL-33-responsive regulatory T cells (Tregs) in mouse models of acute GVHD [101].

The above studies suggest that IL-33 specifically targets ST2-expressing cells such as iNKT cells and Treg cells and functions as a crucial immunomodulator for tolerance induction and suppression of the graft-rejection response in solid organ transplantation $[95,101]$.

\section{Conclusions}

Accumulated evidence indicates that IL-33/ST2 signaling contributes to pathogenesis in multiple diseases that associate with kidney injury. In Table 1, we have summarized recent findings on the IL-33/ST2 axis from clinical and animal studies on kidney diseases. Detection of IL-33 levels in a human fluid specimen largely relies on commercially available ELISA kits. Several studies, however, have demonstrated that the measurement of serum concentrations of IL-33 is challenging and may produce false positive results, which is a caveat for further investigations with serum samples [102-104]. The correlation between serum IL-33 levels and impaired renal function remains controversial; nevertheless, upregulation of tissue IL-33 levels is generally consistent in different renal injury models (Table 1). 
Table 1. Roles of IL-33 and ST2 in renal diseases.

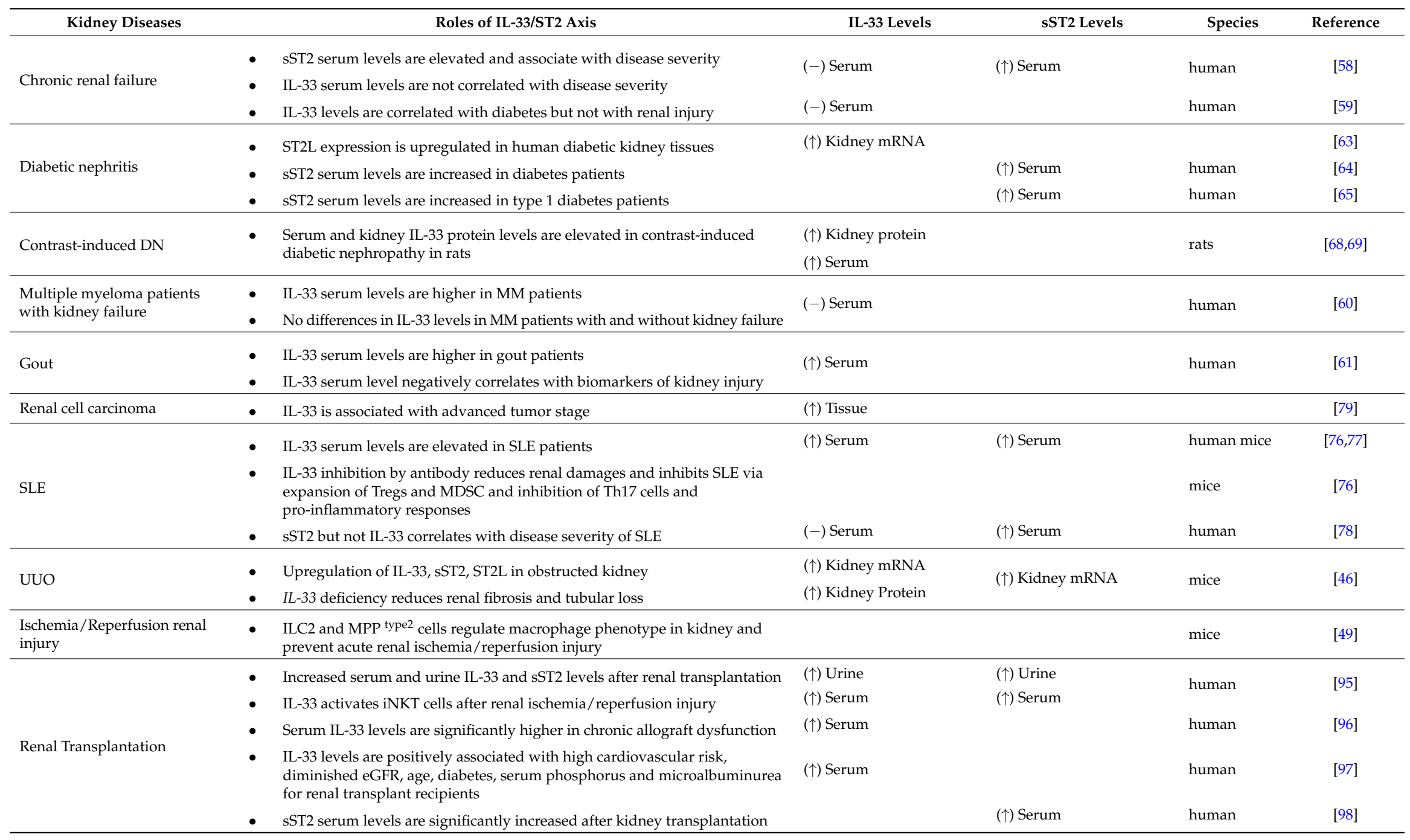


Table 1. Cont.

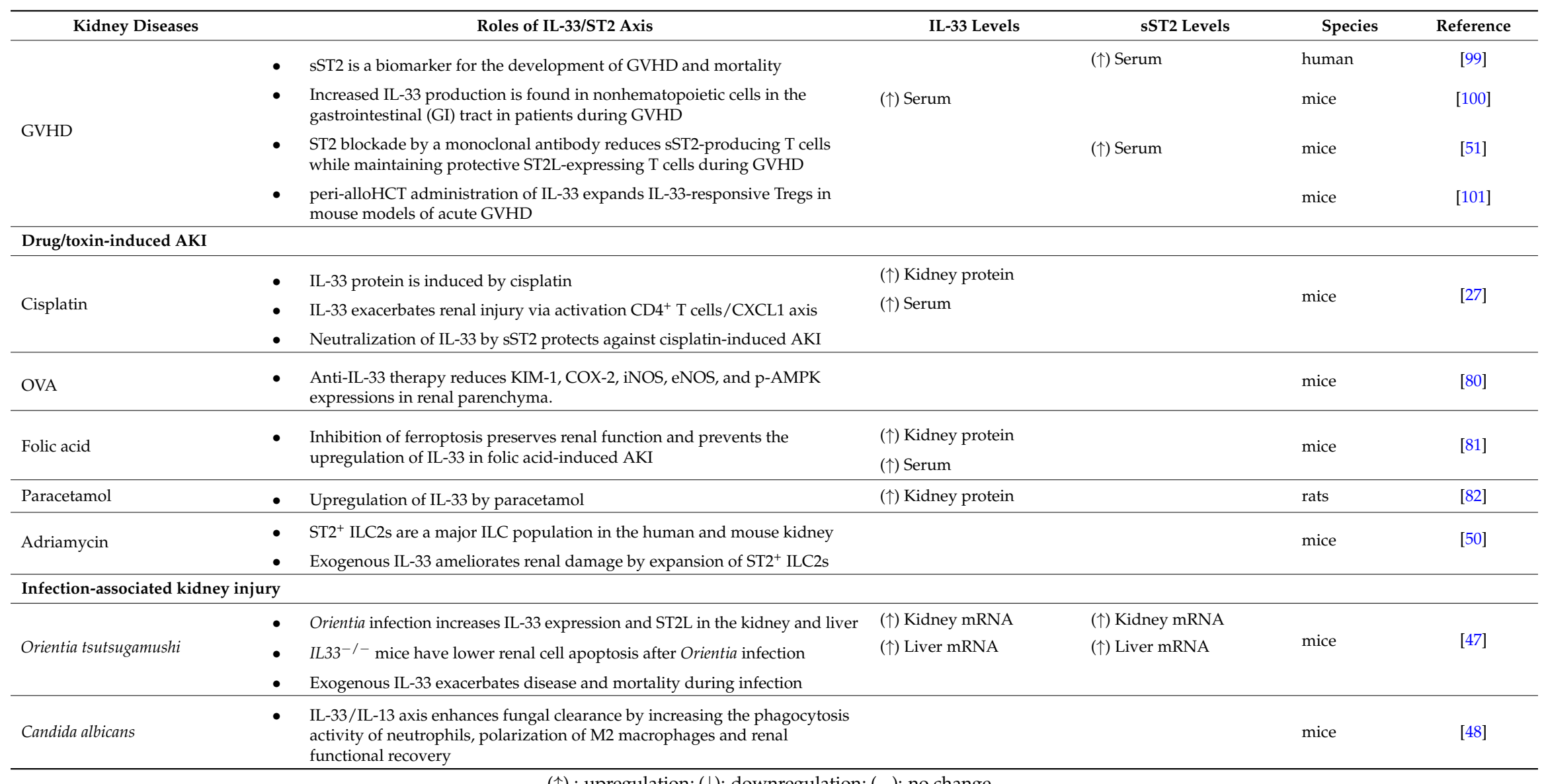

$(\uparrow)$ : upregulation; $(\downarrow)$ : downregulation; (-): no change. 
Exogenous factors (such as drug toxicity, toxins, contrast agents, and chemotherapy), kidney transplantation, and diseases associated with nephropathies (SLE, renal ischemia, and diabetes) lead to upregulation of IL-33 in renal tissue (Figure 1B). After being released, IL-33 elicits both pro-inflammatory and tissue repair responses by activating ST2-expressing cells, including neutrophils, $\mathrm{CD}^{+} \mathrm{T}$ cells, iNKT cells, endothelial cells, ILC2s, and polarized M2 macrophages. Whether IL-33 could target other non-immune cells in the kidney, including proximal tubular cells, distal tubular cells, collecting duct cells, urothelial cells, or podocytes is largely unknown and awaits fully investigation.

Upon tissue injury, IL-33 likely functions as a double-edged sword; on one hand IL-33 is critical for tissue repair or elimination of infection while on the other, excessive production can cause tissue and organ damage. Further investigation is necessary to delineate the precise role of the IL-33/ST2 pathway in the regulation of the balance between tissue inflammation and repair. Better understanding of the pathological role of IL-33 in kidney diseases will help in the development of novel therapeutic strategies for treating or preventing kidney diseases.

Acknowledgments: This work was supported by Chang Gung Medical Foundation (CMRPG8D0231-3 and CMRPG8E0661-3) and Ministry of Science and Technology, Taiwan (MOST105-2628-B-182A-002-MY3). We'd like to thank Kathryn Fischbach for editing written English and Ying-Pin Chen for her assistance in preparation of the graphic illustration.

Conflicts of Interest: The authors declare no conflicts of interest. The founding sponsors had no role in the design of the study; in the collection, analyses, or interpretation of data; in the writing of the manuscript, and in the decision to publish the results.

\section{References}

1. Rewa, O.; Bagshaw, S.M. Acute kidney injury-epidemiology, outcomes and economics. Nat. Rev. Nephrol. 2014, 10, 193-207. [CrossRef] [PubMed]

2. Go, A.S.; Chertow, G.M.; Fan, D.; McCulloch, C.E.; Hsu, C.Y. Chronic kidney disease and the risks of death, cardiovascular events, and hospitalization. N. Engl. J. Med. 2004, 351, 1296-1305. [CrossRef] [PubMed]

3. Bellomo, R.; Kellum, J.A.; Ronco, C. Acute kidney injury. Lancet 2012, 380, 756-766. [CrossRef]

4. Wang, H.E.; Muntner, P.; Chertow, G.M.; Warnock, D.G. Acute kidney injury and mortality in hospitalized patients. Am. J. Nephrol. 2012, 35, 349-355. [CrossRef] [PubMed]

5. Liu, Y. Cellular and molecular mechanisms of renal fibrosis. Nat. Rev. Nephrol. 2011, 7, 684-696. [CrossRef] [PubMed]

6. Rabb, H.; Griffin, M.D.; McKay, D.B.; Swaminathan, S.; Pickkers, P.; Rosner, M.H.; Kellum, J.A.; Ronco, C. Inflammation in AKI: Current understanding, key questions, and knowledge gaps. J. Am. Soc. Nephrol. 2016, 27, 371-379. [CrossRef] [PubMed]

7. London, G.M. Cardiovascular disease in chronic renal failure: Pathophysiologic aspects. Semin. Dial. 2003, 16, 85-94. [CrossRef] [PubMed]

8. Balla, S.; Nusair, M.B.; Alpert, M.A. Risk factors for atherosclerosis in patients with chronic kidney disease: Recognition and management. Curr. Opin. Pharmacol. 2013, 13, 192-199. [CrossRef] [PubMed]

9. Meng, X.M.; Nikolic-Paterson, D.J.; Lan, H.Y. Inflammatory processes in renal fibrosis. Nat. Rev. Nephrol. 2014, 10, 493-503. [CrossRef] [PubMed]

10. Kurts, C.; Panzer, U.; Anders, H.J.; Rees, A.J. The immune system and kidney disease: Basic concepts and clinical implications. Nat. Rev. Immunol. 2013, 13, 738-753. [CrossRef] [PubMed]

11. Akcay, A.; Nguyen, Q.; Edelstein, C.L. Mediators of inflammation in acute kidney injury. Mediat. Inflamm. 2009, 2009, 137072. [CrossRef] [PubMed]

12. Hosohata, K. Role of oxidative stress in drug-induced kidney injury. Int. J. Mol. Sci. 2016, 17, 1826. [CrossRef] [PubMed]

13. Naughton, C.A. Drug-induced nephrotoxicity. Am. Fam. Physician 2008, 78, 743-750. [PubMed]

14. Umbro, I.; Gentile, G.; Tinti, F.; Muiesan, P.; Mitterhofer, A.P. Recent advances in pathophysiology and biomarkers of sepsis-induced acute kidney injury. J. Infect. 2016, 72, 131-142. [CrossRef] [PubMed]

15. Bhattacharjee, N.; Barma, S.; Konwar, N.; Dewanjee, S.; Manna, P. Mechanistic insight of diabetic nephropathy and its pharmacotherapeutic targets: An update. Eur. J. Pharmacol. 2016, 791, 8-24. [CrossRef] [PubMed] 
16. Baekkevold, E.S.; Roussigne, M.; Yamanaka, T.; Johansen, F.E.; Jahnsen, F.L.; Amalric, F.; Brandtzaeg, P.; Erard, M.; Haraldsen, G.; Girard, J.P. Molecular characterization of NF-HEV, a nuclear factor preferentially expressed in human high endothelial venules. Am. J. Pathol. 2003, 163, 69-79. [CrossRef]

17. Schmitz, J.; Owyang, A.; Oldham, E.; Song, Y.; Murphy, E.; McClanahan, T.K.; Zurawski, G.; Moshrefi, M.; Qin, J.; Li, X.; et al. IL-33, an interleukin-1-like cytokine that signals via the IL-1 receptor-related protein ST2 and induces T helper type 2-associated cytokines. Immunity 2005, 23, 479-490. [CrossRef] [PubMed]

18. Cayrol, C.; Girard, J.P. IL-33: An alarmin cytokine with crucial roles in innate immunity, inflammation and allergy. Curr. Opin. Immunol. 2014, 31, 31-37. [CrossRef] [PubMed]

19. Pichery, M.; Mirey, E.; Mercier, P.; Lefrancais, E.; Dujardin, A.; Ortega, N.; Girard, J.P. Endogenous IL-33 is highly expressed in mouse epithelial barrier tissues, lymphoid organs, brain, embryos, and inflamed tissues: In situ analysis using a novel IL-33-LacZ gene trap reporter strain. J. Immunol. 2012, 188, 3488-3495. [CrossRef] [PubMed]

20. Milovanovic, M.; Volarevic, V.; Radosavljevic, G.; Jovanovic, I.; Pejnovic, N.; Arsenijevic, N.; Lukic, M.L. IL-33/ST2 axis in inflammation and immunopathology. Immunol. Res. 2012, 52, 89-99. [CrossRef] [PubMed]

21. Kakkar, R.; Hei, H.; Dobner, S.; Lee, R.T. Interleukin 33 as a mechanically responsive cytokine secreted by living cells. J. Biol. Chem. 2012, 287, 6941-6948. [CrossRef] [PubMed]

22. Iwahana, H.; Yanagisawa, K.; Ito-Kosaka, A.; Kuroiwa, K.; Tago, K.; Komatsu, N.; Katashima, R.; Itakura, M.; Tominaga, S. Different promoter usage and multiple transcription initiation sites of the interleukin-1 receptor-related human ST2 gene in UT-7 and TM12 cells. Eur. J. Biochem. 1999, 264, 397-406. [CrossRef] [PubMed]

23. De la Fuente, M.; MacDonald, T.T.; Hermoso, M.A. The IL-33/ST2 axis: Role in health and disease. Cytokine Growth Factor Rev. 2015, 26, 615-623. [CrossRef] [PubMed]

24. Moussion, C.; Ortega, N.; Girard, J.P. The IL-1-like cytokine IL-33 is constitutively expressed in the nucleus of endothelial cells and epithelial cells in vivo: A novel "alarmin"? PLoS ONE 2008, 3, e3331. [CrossRef] [PubMed]

25. Arshad, M.I.; Guihard, P.; Danger, Y.; Noel, G.; Le Seyec, J.; Boutet, M.A.; Richards, C.D.; L'Helgoualc'h, A.; Genet, V.; Lucas-Clerc, C.; et al. Oncostatin M induces IL-33 expression in liver endothelial cells in mice and expands ST2 ${ }^{+} \mathrm{CD} 4{ }^{+}$lymphocytes. Am. J. Physiol. Gastrointest. Liver Physiol. 2015, 309, G542-G553. [CrossRef] [PubMed]

26. Chen, W.Y.; Hong, J.; Gannon, J.; Kakkar, R.; Lee, R.T. Myocardial pressure overload induces systemic inflammation through endothelial cell IL-33. Proc. Natl. Acad. Sci. USA 2015, 112, 7249-7254. [CrossRef] [PubMed]

27. Akcay, A.; Nguyen, Q.; He, Z.; Turkmen, K.; Won Lee, D.; Hernando, A.A.; Altmann, C.; Toker, A.; Pacic, A.; Ljubanovic, D.G.; et al. IL-33 exacerbates acute kidney injury. J. Am. Soc. Nephrol. 2011, 22, 2057-2067. [CrossRef] [PubMed]

28. Cayrol, C.; Girard, J.P. The IL-1-like cytokine IL-33 is inactivated after maturation by caspase-1. Proc. Natl. Acad. Sci. USA 2009, 106, 9021-9026. [CrossRef] [PubMed]

29. Luthi, A.U.; Cullen, S.P.; McNeela, E.A.; Duriez, P.J.; Afonina, I.S.; Sheridan, C.; Brumatti, G.; Taylor, R.C.; Kersse, K.; Vandenabeele, P.; et al. Suppression of interleukin-33 bioactivity through proteolysis by apoptotic caspases. Immunity 2009, 31, 84-98. [CrossRef] [PubMed]

30. Roussel, L.; Erard, M.; Cayrol, C.; Girard, J.P. Molecular mimicry between IL-33 and KSHV for attachment to chromatin through the H2A-H2B acidic pocket. EMBO Rep. 2008, 9, 1006-1012. [CrossRef] [PubMed]

31. Gautier, V.; Cayrol, C.; Farache, D.; Roga, S.; Monsarrat, B.; Burlet-Schiltz, O.; Gonzalez de Peredo, A.; Girard, J.P. Extracellular IL-33 cytokine, but not endogenous nuclear IL-33, regulates protein expression in endothelial cells. Sci. Rep. 2016, 6, 34255. [CrossRef] [PubMed]

32. Ali, S.; Mohs, A.; Thomas, M.; Klare, J.; Ross, R.; Schmitz, M.L.; Martin, M.U. The dual function cytokine IL-33 interacts with the transcription factor NF- $\mathrm{kB}$ to dampen NF- $\mathrm{kB}$-stimulated gene transcription. J. Immunol. 2011, 187, 1609-1616. [CrossRef] [PubMed]

33. Ni, Y.; Tao, L.; Chen, C.; Song, H.; Li, Z.; Gao, Y.; Nie, J.; Piccioni, M.; Shi, G.; Li, B. The deubiquitinase USP17 regulates the stability and nuclear function of IL-33. Int. J. Mol. Sci. 2015, 16, 27956-27966. [CrossRef] [PubMed] 
34. Monticelli, L.A.; Sonnenberg, G.F.; Abt, M.C.; Alenghat, T.; Ziegler, C.G.; Doering, T.A.; Angelosanto, J.M.; Laidlaw, B.J.; Yang, C.Y.; Sathaliyawala, T.; et al. Innate lymphoid cells promote lung-tissue homeostasis after infection with influenza virus. Nat. Immunol. 2011, 12, 1045-1054. [CrossRef] [PubMed]

35. Chang, Y.J.; Kim, H.Y.; Albacker, L.A.; Baumgarth, N.; McKenzie, A.N.; Smith, D.E.; Dekruyff, R.H.; Umetsu, D.T. Innate lymphoid cells mediate influenza-induced airway hyper-reactivity independently of adaptive immunity. Nat. Immunol. 2011, 12, 631-638. [CrossRef] [PubMed]

36. Yasuda, K.; Muto, T.; Kawagoe, T.; Matsumoto, M.; Sasaki, Y.; Matsushita, K.; Taki, Y.; Futatsugi-Yumikura, S.; Tsutsui, H.; Ishii, K.J.; et al. Contribution of IL-33-activated type II innate lymphoid cells to pulmonary eosinophilia in intestinal nematode-infected mice. Proc. Natl. Acad. Sci. USA 2012, 109, 3451-3456. [CrossRef] [PubMed]

37. Lefrancais, E.; Roga, S.; Gautier, V.; Gonzalez-de-Peredo, A.; Monsarrat, B.; Girard, J.P.; Cayrol, C. IL-33 is processed into mature bioactive forms by neutrophil elastase and cathepsin G. Proc. Natl. Acad. Sci. USA 2012, 109, 1673-1678. [CrossRef] [PubMed]

38. Cohen, E.S.; Scott, I.C.; Majithiya, J.B.; Rapley, L.; Kemp, B.P.; England, E.; Rees, D.G.; Overed-Sayer, C.L.; Woods, J.; Bond, N.J.; et al. Oxidation of the alarmin IL-33 regulates ST2-dependent inflammation. Nat. Commun. 2015, 6, 8327. [CrossRef] [PubMed]

39. Bessa, J.; Meyer, C.A.; de Vera Mudry, M.C.; Schlicht, S.; Smith, S.H.; Iglesias, A.; Cote-Sierra, J. Altered subcellular localization of IL-33 leads to non-resolving lethal inflammation. J. Autoimmun. 2014, 55, $33-41$. [CrossRef] [PubMed]

40. Nagarkar, D.R.; Ramirez-Carrozzi, V.; Choy, D.F.; Lee, K.; Soriano, R.; Jia, G.; Abbas, A.R.; Modrusan, Z.; Pappu, R.; Arron, J.R. IL-13 mediates IL-33-dependent mast cell and type 2 innate lymphoid cell effects on bronchial epithelial cells. J. Allergy Clin. Immunol. 2015, 136, 202-205. [CrossRef] [PubMed]

41. Kim, H.Y.; Chang, Y.J.; Subramanian, S.; Lee, H.H.; Albacker, L.A.; Matangkasombut, P.; Savage, P.B.; McKenzie, A.N.; Smith, D.E.; Rottman, J.B.; et al. Innate lymphoid cells responding to IL-33 mediate airway hyperreactivity independently of adaptive immunity. J. Allergy Clin. Immunol. 2012, 129, 216-227. [CrossRef] [PubMed]

42. Martin, N.T.; Martin, M.U. Interleukin 33 is a guardian of barriers and a local alarmin. Nat. Immunol. 2016, 17, 122-131. [CrossRef] [PubMed]

43. Molofsky, A.B.; Savage, A.K.; Locksley, R.M. Interleukin-33 in tissue homeostasis, injury, and inflammation. Immunity 2015, 42, 1005-1019. [CrossRef] [PubMed]

44. Yang, F.; Zhu, P.; Duan, L.; Yang, L.; Wang, J. IL-33 and kidney disease (Review). Mol. Med. Rep. 2016, 13, 3-8. [CrossRef] [PubMed]

45. Li, D.; Guabiraba, R.; Besnard, A.G.; Komai-Koma, M.; Jabir, M.S.; Zhang, L.; Graham, G.J.; Kurowska-Stolarska, M.; Liew, F.Y.; McSharry, C.; et al. IL-33 promotes ST2-dependent lung fibrosis by the induction of alternatively activated macrophages and innate lymphoid cells in mice. J. Allergy Clin. Immunol. 2014, 134, 1422-1432. [CrossRef] [PubMed]

46. Chen, W.Y.; Chang, Y.J.; Su, C.H.; Tsai, T.H.; Chen, S.D.; Hsing, C.H.; Yang, J.L. Upregulation of Interleukin-33 in obstructive renal injury. Biochem. Biophys. Res. Commun. 2016, 473, 1026-1032. [CrossRef] [PubMed]

47. Shelite, T.R.; Liang, Y.; Wang, H.; Mendell, N.L.; Trent, B.J.; Sun, J.; Gong, B.; Xu, G.; Hu, H.; Bouyer, D.H.; et al. IL-33-dependent endothelial activation contributes to apoptosis and renal injury in orientia tsutsugamushi-infected mice. PLoS Negl. Trop. Dis. 2016, 10, e0004467. [CrossRef] [PubMed]

48. Tran, V.G.; Kim, H.J.; Kim, J.; Kang, S.W.; Moon, U.J.; Cho, H.R.; Kwon, B. IL-33 enhances host tolerance to candida albicans kidney infections through induction of IL-13 production by CD4 ${ }^{+}$T cells. J. Immunol. 2015, 194, 4871-4879. [CrossRef] [PubMed]

49. Huang, Q.; Niu, Z.; Tan, J.; Yang, J.; Liu, Y.; Ma, H.; Lee, V.W.; Sun, S.; Song, X.; Guo, M.; et al. IL-25 elicits innate lymphoid cells and multipotent progenitor type 2 cells that reduce renal ischemic/reperfusion injury. J. Am. Soc. Nephrol. 2015, 26, 2199-2211. [CrossRef] [PubMed]

50. Riedel, J.H.; Becker, M.; Kopp, K.; Duster, M.; Brix, S.R.; Meyer-Schwesinger, C.; Kluth, L.A.; Gnirck, A.C.; Attar, M.; Krohn, S.; et al. IL-33-mediated expansion of type 2 innate lymphoid cells protects from progressive glomerulosclerosis. J. Am. Soc. Nephrol. 2017. [CrossRef] [PubMed]

51. Zhang, J.; Ramadan, A.M.; Griesenauer, B.; Li, W.; Turner, M.J.; Liu, C.; Kapur, R.; Hanenberg, H.; Blazar, B.R.; Tawara, I.; et al. ST2 blockade reduces sST2-producing T cells while maintaining protective mST2-expressing T cells during graft-versus-host disease. Sci. Transl. Med. 2015. [CrossRef] [PubMed] 
52. Demyanets, S.; Kaun, C.; Pentz, R.; Krychtiuk, K.A.; Rauscher, S.; Pfaffenberger, S.; Zuckermann, A.; Aliabadi, A.; Groger, M.; Maurer, G.; et al. Components of the interleukin-33/ST2 system are differentially expressed and regulated in human cardiac cells and in cells of the cardiac vasculature. J. Mol. Cell. Cardiol. 2013, 60, 16-26. [CrossRef] [PubMed]

53. Bartunek, J.; Delrue, L.; van Durme, F.; Muller, O.; Casselman, F.; de Wiest, B.; Croes, R.; Verstreken, S.; Goethals, M.; de Raedt, H.; et al. Nonmyocardial production of ST2 protein in human hypertrophy and failure is related to diastolic load. J. Am. Coll. Cardiol. 2008, 52, 2166-2174. [CrossRef] [PubMed]

54. Kidney Disease: Improving Global Outcomes (KDIGO) CKD Work Group. KDIGO 2012 Clinical Practice Guideline for the Evaluation and Management of Chronic Kidney Disease. Kidney Int. Suppl. 2013, 3, 1-150.

55. Bjornsson, T.D. Use of serum creatinine concentrations to determine renal function. Clin. Pharmacokinet. 1979, 4, 200-222. [CrossRef] [PubMed]

56. Waikar, S.S.; Betensky, R.A.; Bonventre, J.V. Creatinine as the gold standard for kidney injury biomarker studies? Nephrol. Dial. Transplant. 2009, 24, 3263-3265. [CrossRef] [PubMed]

57. Bellomo, R.; Kellum, J.A.; Ronco, C. Defining acute renal failure: Physiological principles. Intensive Care Med. 2004, 30, 33-37. [CrossRef] [PubMed]

58. Bao, Y.S.; Na, S.P.; Zhang, P.; Jia, X.B.; Liu, R.C.; Yu, C.Y.; Mu, S.H.; Xie, R.J. Characterization of interleukin-33 and soluble ST2 in serum and their association with disease severity in patients with chronic kidney disease. J. Clin. Immunol. 2012, 32, 587-594. [CrossRef] [PubMed]

59. Caner, S.; Usluogullari, C.A.; Balkan, F.; Buyukcam, F.; Kaya, C.; Sacikara, M.; Koca, C.; Ersoy, R.; Cakir, B. Is IL-33 useful to detect early stage of renal failure? Renal Fail. 2014, 36, 78-80. [CrossRef] [PubMed]

60. Musolino, C.; Allegra, A.; Profita, M.; Alonci, A.; Saitta, S.; Russo, S.; Bonanno, A.; Innao, V.; Gangemi, S. Reduced IL-33 plasma levels in multiple myeloma patients are associated with more advanced stage of disease. Br. J. Haematol. 2013, 160, 709-710. [CrossRef] [PubMed]

61. Duan, L.; Huang, Y.; Su, Q.; Lin, Q.; Liu, W.; Luo, J.; Yu, B.; He, Y.; Qian, H.; Liu, Y.; et al. Potential of IL-33 for preventing the kidney injury via regulating the lipid metabolism in gout patients. J. Diabetes Res. 2016, 2016, 1028401. [CrossRef] [PubMed]

62. Lim, A.K.; Tesch, G.H. Inflammation in diabetic nephropathy. Mediat. Inflamm. 2012, 2012, 146154. [CrossRef] [PubMed]

63. Chen, N.K.; Chong, T.W.; Loh, H.L.; Lim, K.H.; Gan, V.H.; Wang, M.; Kon, O.L. Negative regulatory responses to metabolically triggered inflammation impair renal epithelial immunity in diabetes mellitus. J. Mol. Med. 2013, 91, 587-598. [CrossRef] [PubMed]

64. Caporali, A.; Meloni, M.; Miller, A.M.; Vierlinger, K.; Cardinali, A.; Spinetti, G.; Nailor, A.; Faglia, E.; Losa, S.; Gotti, A.; et al. Soluble ST2 is regulated by p75 neurotrophin receptor and predicts mortality in diabetic patients with critical limb ischemia. Arterioscler. Thromb. Vasc. Biol. 2012, 32, e149-e160. [CrossRef] [PubMed]

65. Ryba-Stanislawowska, M.; Werner, P.; Skrzypkowska, M.; Brandt, A.; Mysliwska, J. IL-33 effect on quantitative changes of $\mathrm{CD} 4^{+} \mathrm{CD} 25^{\text {highFOXP3+ }}$ regulatory $\mathrm{T}$ cells in children with type 1 diabetes. Mediat. Inflamm. 2016, 2016, 9429760. [CrossRef] [PubMed]

66. Miller, A.M.; Purves, D.; McConnachie, A.; Asquith, D.L.; Batty, G.D.; Burns, H.; Cavanagh, J.; Ford, I.; McLean, J.S.; Packard, C.J.; et al. Soluble ST2 associates with diabetes but not established cardiovascular risk factors: A new inflammatory pathway of relevance to diabetes? PLoS ONE 2012, 7, e47830. [CrossRef] [PubMed]

67. Calvin, A.D.; Misra, S.; Pflueger, A. Contrast-induced acute kidney injury and diabetic nephropathy. Nat. Rev. Nephrol. 2010, 6, 679-688. [CrossRef] [PubMed]

68. Onk, D.; Onk, O.A.; Turkmen, K.; Erol, H.S.; Ayazoglu, T.A.; Keles, O.N.; Halici, M.; Topal, E. Melatonin attenuates contrast-induced nephropathy in diabetic rats: The role of Interleukin-33 and oxidative stress. Mediat. Inflamm. 2016, 2016, 9050828. [CrossRef] [PubMed]

69. Demirtas, L.; Turkmen, K.; Kandemir, F.M.; Ozkaraca, M.; Kucukler, S.; Gurbuzel, M.; Comakli, S. The possible role of interleukin-33 as a new player in the pathogenesis of contrast-induced nephropathy in diabetic rats. Ren. Fail. 2016, 38, 952-960. [CrossRef] [PubMed]

70. Weening, J.J.; D'Agati, V.D.; Schwartz, M.M.; Seshan, S.V.; Alpers, C.E.; Appel, G.B.; Balow, J.E.; Bruijn, J.A.; Cook, T.; Ferrario, F.; et al. The classification of glomerulonephritis in systemic lupus erythematosus revisited. J. Am. Soc. Nephrol. 2004, 15, 241-250. [CrossRef] [PubMed] 
71. Lourenco, E.V.; la Cava, A. Cytokines in systemic lupus erythematosus. Curr. Mol. Med. 2009, 9, $242-254$. [CrossRef] [PubMed]

72. Koutsokeras, T.; Healy, T. Systemic lupus erythematosus and lupus nephritis. Nat. Rev. Drug Discov. 2014, 13, 173-174. [CrossRef] [PubMed]

73. Bomback, A.S.; Appel, G.B. Updates on the treatment of lupus nephritis. J. Am. Soc. Nephrol. JASN 2010, 21, 2028-2035. [CrossRef] [PubMed]

74. Wang, L.; Law, H.K. The Role of Autophagy in Lupus Nephritis. Int. J. Mol. Sci. 2015, 16, $25154-25167$. [CrossRef] [PubMed]

75. Yu, S.L.; Wong, C.K.; Tam, L.S. The alarmin functions of high-mobility group box-1 and IL-33 in the pathogenesis of systemic lupus erythematosus. Expert Rev. Clin. Immunol. 2013, 9, 739-749. [CrossRef] [PubMed]

76. Li, P.; Lin, W.; Zheng, X. IL-33 neutralization suppresses lupus disease in lupus-prone mice. Inflammation 2014, 37, 824-832. [CrossRef] [PubMed]

77. Yang, Z.; Liang, Y.; Xi, W.; Li, C.; Zhong, R. Association of increased serum IL-33 levels with clinical and laboratory characteristics of systemic lupus erythematosus in Chinese population. Clin. Exp. Med. 2011, 11, 75-80. [CrossRef] [PubMed]

78. Mok, M.Y.; Huang, F.P.; Ip, W.K.; Lo, Y.; Wong, F.Y.; Chan, E.Y.; Lam, K.F.; Xu, D. Serum levels of IL-33 and soluble ST2 and their association with disease activity in systemic lupus erythematosus. Rheumatology 2010, 49, 520-527. [CrossRef] [PubMed]

79. Wang, Z.; Xu, L.; Chang, Y.; Zhou, L.; Fu, H.; Zhang, W.; Yang, Y.; Xu, J. IL-33 is associated with unfavorable postoperative survival of patients with clear-cell renal cell carcinoma. Tumour Biol. 2016, 37, 11127-11134. [CrossRef] [PubMed]

80. Park, G.H.; Shinn, H.K.; Kang, J.H.; Na, W.J.; Kim, Y.H.; Park, C.S. Anti-interleukin-33 reduces ovalbumin-induced nephrotoxicity and expression of kidney injury molecule-1. Int. Neurourol. J. 2016, 20, 114-121. [CrossRef] [PubMed]

81. Martin-Sanchez, D.; Ruiz-Andres, O.; Poveda, J.; Carrasco, S.; Cannata-Ortiz, P.; Sanchez-Nino, M.D.; m; Egido, J.; Linkermann, A.; Ortiz, A.; et al. Ferroptosis, but not necroptosis, is important in nephrotoxic folic acid-induced AKI. J. Am. Soc. Nephrol. JASN 2017, 28, 218-229. [CrossRef] [PubMed]

82. Kandemir, F.M.; Kucukler, S.; Eldutar, E.; Caglayan, C.; Gulcin, I. Chrysin protects rat kidney from paracetamol-induced oxidative stress, inflammation, apoptosis, and autophagy: A multi-biomarker approach. Sci. Pharm. 2017, 85, 4. [CrossRef] [PubMed]

83. Forbes, M.S.; Thornhill, B.A.; Minor, J.J.; Gordon, K.A.; Galarreta, C.I.; Chevalier, R.L. Fight-or-flight: Murine unilateral ureteral obstruction causes extensive proximal tubular degeneration, collecting duct dilatation, and minimal fibrosis. Am. J. Physiol. Ren. Physiol. 2012, 303, 120-129. [CrossRef] [PubMed]

84. Chevalier, R.L.; Forbes, M.S.; Thornhill, B.A. Ureteral obstruction as a model of renal interstitial fibrosis and obstructive nephropathy. Kidney Int. 2009, 75, 1145-1152. [CrossRef] [PubMed]

85. Kouzaki, H.; Iijima, K.; Kobayashi, T.; O'Grady, S.M.; Kita, H. The danger signal, extracellular ATP, is a sensor for an airborne allergen and triggers IL-33 release and innate Th2-type responses. J. Immunol. 2011, 186, 4375-4387. [CrossRef] [PubMed]

86. Hardman, C.; Ogg, G. Interleukin-33, friend and foe in type-2 immune responses. Curr. Opin. Immunol. 2016, 42, 16-24. [CrossRef] [PubMed]

87. Lakshmikanth, C.L.; Jacob, S.P.; Chaithra, V.H.; de Castro-Faria-Neto, H.C.; Marathe, G.K. Sepsis: In search of cure. Inflamm. Res. 2016, 65, 587-602. [CrossRef] [PubMed]

88. Xu, H.; Turnquist, H.R.; Hoffman, R.; Billiar, T.R. Role of the IL-33-ST2 axis in sepsis. Mil. Med. Res. 2017, 4, 3. [CrossRef] [PubMed]

89. Cekmez, F.; Fidanci, M.K.; Ayar, G.; Saldir, M.; Karaoglu, A.; Gunduz, R.C.; Tunc, T.; Kalkan, G. Diagnostic value of upar, IL-33, and ST2 levels in childhood sepsis. Clin. Lab. 2016, 62, 751-755. [CrossRef] [PubMed]

90. Brunner, M.; Krenn, C.; Roth, G.; Moser, B.; Dworschak, M.; Jensen-Jarolim, E.; Spittler, A.; Sautner, T.; Bonaros, N.; Wolner, E.; et al. Increased levels of soluble ST2 protein and IgG1 production in patients with sepsis and trauma. Intensive Care Med. 2004, 30, 1468-1473. [CrossRef] [PubMed]

91. Hoogerwerf, J.J.; Tanck, M.W.; van Zoelen, M.A.; Wittebole, X.; Laterre, P.F.; van der Poll, T. Soluble ST2 plasma concentrations predict mortality in severe sepsis. Intensive Care Med. 2010, 36, 630-637. [CrossRef] [PubMed] 
92. Parenica, J.; Malaska, J.; Jarkovsky, J.; Lipkova, J.; Dastych, M.; Helanova, K.; Litzman, J.; Tomandl, J.; Littnerova, S.; Sevcikova, J.; et al. Soluble ST2 levels in patients with cardiogenic and septic shock are not predictors of mortality. Exp. Clin. Cardiol. 2012, 17, 205-209. [PubMed]

93. Attur, R.P.; Kuppasamy, S.; Bairy, M.; Nagaraju, S.P.; Pammidi, N.R.; Kamath, V.; Kamath, A.; Rao, L.; Bairy, I. Acute kidney injury in scrub typhus. Clin. Exp. Nephrol. 2013, 17, 725-729. [CrossRef] [PubMed]

94. Le, H.T.; Tran, V.G.; Kim, W.; Kim, J.; Cho, H.R.; Kwon, B. IL-33 priming regulates multiple steps of the neutrophil-mediated anti-candida albicans response by modulating TLR and dectin-1 signals. J. Immunol. 2012, 189, 287-295. [CrossRef] [PubMed]

95. Thierry, A.; Giraud, S.; Robin, A.; Barra, A.; Bridoux, F.; Ameteau, V.; Hauet, T.; Girard, J.P.; Touchard, G.; Gombert, J.M.; et al. The alarmin concept applied to human renal transplantation: Evidence for a differential implication of HMGB1 and IL-33. PLoS ONE 2014, 9, e88742. [CrossRef] [PubMed]

96. Zhang, J.; Wang, Z.; Xu, Z.; Han, Z.; Tao, J.; Lu, P.; Huang, Z.; Zhou, W.; Zhao, C.; Tan, R.; et al. The potential role of IL-33 in renal transplant recipients with chronic allograft dysfunction. Ann. Transpl. 2016, 21, 611-618. [CrossRef] [PubMed]

97. Mansell, H.; Soliman, M.; Elmoselhi, H.; Shoker, A. Elevated circulating Interleukin 33 levels in stable renal transplant recipients at high risk for cardiovascular events. PLoS ONE 2015, 10, e0142141. [CrossRef] [PubMed]

98. Bruneau, S.; Le Berre, L.; Herve, C.; Valanciute, A.; Kamal, M.; Naulet, J.; Tesson, L.; Foucher, Y.; Soulillou, J.P.; Sahali, D.; et al. Potential role of soluble ST2 protein in idiopathic nephrotic syndrome recurrence following kidney transplantation. Am. J. Kidney Dis. 2009, 54, 522-532. [CrossRef] [PubMed]

99. Vander Lugt, M.T.; Braun, T.M.; Hanash, S.; Ritz, J.; Ho, V.T.; Antin, J.H.; Zhang, Q.; Wong, C.H.; Wang, H.; Chin, A.; et al. ST2 as a marker for risk of therapy-resistant graft-versus-host disease and death. N. Engl. J. Med. 2013, 369, 529-539. [CrossRef] [PubMed]

100. Reichenbach, D.K.; Schwarze, V.; Matta, B.M.; Tkachev, V.; Lieberknecht, E.; Liu, Q.; Koehn, B.H.; Pfeifer, D.; Taylor, P.A.; Prinz, G.; et al. The IL-33/ST2 axis augments effector T-cell responses during acute GVHD. Blood 2015, 125, 3183-3192. [CrossRef] [PubMed]

101. Matta, B.M.; Reichenbach, D.K.; Zhang, X.; Mathews, L.; Koehn, B.H.; Dwyer, G.K.; Lott, J.M.; Uhl, F.M.; Pfeifer, D.; Feser, C.J.; et al. Peri-alloHCT IL-33 administration expands recipient T-regulatory cells that protect mice against acute GVHD. Blood 2016, 128, 427-439. [CrossRef] [PubMed]

102. Nygaard, U.; Vestergaard, C.; Johansen, C.; Deleuran, M.; Hvid, M. Measuring serum concentrations of interleukin-33 in atopic dermatitis is associated with potential false positive results. Springerplus 2016, 5, 33. [CrossRef] [PubMed]

103. Ketelaar, M.E.; Nawijn, M.C.; Shaw, D.E.; Koppelman, G.H.; Sayers, I. The challenge of measuring IL-33 in serum using commercial ELISA: Lessons from asthma. Clin. Exp. Allergy 2016, 46, 884-887. [CrossRef] [PubMed]

104. Riviere, E.; Ly, B.; Boudaoud, S.; Chavez, H.; Nocturne, G.; Chanson, P.; Miceli Richard, C.; Mariette, X. Pitfalls for detecting interleukin-33 by ELISA in the serum of patients with primary Sjogren syndrome: Comparison of different kits. Ann. Rheum. Dis. 2016, 75, 633-635. [CrossRef] [PubMed]

(C) 2017 by the authors. Licensee MDPI, Basel, Switzerland. This article is an open access article distributed under the terms and conditions of the Creative Commons Attribution (CC BY) license (http:/ / creativecommons.org/licenses/by/4.0/). 